\title{
Brain plasticity of rats exposed to prenatal immobilization stress
}

\author{
S. S. Abrahamyan, I. B. Meliksetyan ${ }^{1}$, I. K. Sahakyan, N. V. Tumasyan, \\ B. Yu. Badalyan', A. A. Galoyan
}

H. Buniatian Institute of Biochemistry, NAS of Republic of Armenia

5/1, P. Sevak Str., Yerevan, Republic of Armenia, 0014

${ }^{1}$ L. A. Orbeli Institute of Physiology, NAS of Republic of Armenia

22, Orbeli Str., Yerevan, Republic of Armenia, 0028

${ }^{2}$ Yerevan State Medical University named after Mkhitar Heratsi, Ministry of Education and Science of Republic of Armenia 2, Koryun Str., Yerevan, Republic of Armenia, 0025

inesa555@rambler.ru

\begin{abstract}
Aim. This histochemical and immunohistochemical study was aimed at examining the brain cellular structures of newborn rats exposed to prenatal immobilization (IMO) stress. Methods. Histochemical method on detection of $\mathrm{Ca}^{2+}$-dependent acid phosphatase activity and ABC immunohistochemical technique. Results. Cell structures with radial astrocytes marker GFAP, neuroepithelial stem cell marker gene nestin, stem-cells marker and the hypothalamic neuroprotective proline-rich polypeptide PRP-1 (aka Galarmin, a natural cytokine of a common precursor to neurophysin vasopressin associated glycoprotein) have been revealed in several brain regions. Conclusions. Our findings indicate the process of generation of new neurons in response to IMO and PRP-1 involvement in this recovery mechanism, as PRP-1-Ir was detected in the above mentioned cell structures, as well as in the neurons and nerve fibers.
\end{abstract}

Keywords: rat brain plasticity, prenatal immobilization stress, GFAP-, nestin-, stem cells-, and PRP-1-immunoreactive structures.

Introduction. A new type of cytokines of the neurosecretory hypothalamus, the proline rich peptides, isolated from bovine neurohypophysis neurosecretory granules are synthesized in the form of a common precursor protein (neurophysin vasopressin associated glycoprotein) [1]. In the biochemical, immunological, and physiological studies, proline-rich peptide-1 (PRP-1, 15 amino acid residues) has been shown to possess antitumor effect $[2,3]$; strong antiviral and antibacterial activity [4-6]. Under several pathological conditions, PRP-1 has been shown to be a universal neuroprotector and neuromodulator $[7,8]$. Our previous report on the effects of PRP-1 on spinal cord (SC) injured rats indicated the possibility of PRP-1 involvement in the mechanisms of neuronal repair.

(C) Institute of Molecular Biology and Genetics, NAS of Ukraine, 2011
Neuroplasticity is a nervous system ability to change at any age and modify its organization and function. Adult brain cell regeneration (neurogenesis, the process of generating new neurons) is demonstrated in many species, including rodents. Its primary functions are to maintain cell homeostasis and to replace cells that die because of injury or disease $[9,10]$. The list of adult tissues reported to contain stem cells is growing and includes bone marrow, peripheral blood, brain, spinal cord. Brain plasticity and behavior can be influenced by myriad of factors, including drugs, hormones, maturation, aging, disease, and stress.

Understanding how these factors influence brain organization and function is important not only for understanding both normal and abnormal behavior, but also for designing treatments for behavioral and psychological disorders. 
The purpose of the present histochemical and immunohistochemical study was to examine the stress-induced response of brain structures in the rats exposed to the prenatal immobilization (IMO) stress, and to investigate the mechanisms underlying the putative neurogenesis processes.

Materials and methods. White laboratory male rats, $80-100 \mathrm{~g}$ body weight, were divided into two groups: 1) intact rats $(n=5)$, and 2) rats exposed to the acute 120 min prenatal immobilization stress $(n=3)$.

Following the anesthesia with Nembutal (40-50 mg/ $\mathrm{kg}$ ), non-perfused control and experimental rats were decapitated and the brains and spanal cords were rapidly removed and fixed in $4 \%$ paraformaldehyde prepared in $0.1 \mathrm{M}$ phosphate buffer, $\mathrm{pH}=7.4$ for $48 \mathrm{~h}$ at $4{ }^{\circ} \mathrm{C}$. Then, the tissues were cryoprotected for $24 \mathrm{~h}$ in $0.1 \mathrm{M}$ phosphate buffered saline containing $30 \%$ sucrose.

$50-\mu \mathrm{m}$ free-floating freezing microtome sections were then processed using immunohistochemistry with the Avidin-Biotin-Peroxidase Complex technique [11] and histochemistry by the method on detection of $\mathrm{Ca}^{2+}$ dependent acid phosphatase (Aph) activity [12].

The primary polyclonal antiserum against the PRP1 in 1:5000 dilution obtained by us according to Ambrosius [13] and monoclonal antisera against the neuroepithelial stem cell marker nestin, astrocytes marker GFAP and mouse stem cells in 1:2000 dilution were used for immunohistochemistry.

Results and discussion. According to histochemical data regarding the Aph activity detection in response to IMO stress, densely stained cells of different sizes and shapes are found in the brain white matter (Fig. 1, see inset). Cells resembling mesenchyme cells (Fig. 1, $C$ ) and many round cells in a blood vessel (Fig. 1, D) are demonstrated in the cerebellum. A number of cells, most likely pericapillary pericytes, covered the capillaries and situated in the perivascular area (Fig. 1, E,F).

Angiogenesis in the developing tissue is known to be a universal process accompanying, in fact, practically all morphological events. And very often, the vessels growth, in particular, determines the intensity of proliferation, differentiation, and formation of new histological structures. Angiogenesis mentioned seems to be the exact reflection of the results presented by Pelletier and coworkers [14], who demonstrated a culture system for human bone marrow endothelial cells that under the action of tachykinins organize into capillary tubes associated to pericytes.
It is also known that transplanted bone marrow (BM) cells in the brain can differentiate into parenchymal microglial cells and perivascular cells [15].

There was determined that environmental changes could alter behavior and cognition by modifying connections between existing neurons and via neurogenesis in the hippocampus and other parts of the brain, including SC and the cerebellum [16].

Immunohistochemical analysis revealed tha PRP1-immunoreactive (PRP-1-Ir) varicose fibers and varicosities surrounded the cells in almost all brain regions including the n. Cochlearis (Fig. 2, $A$, see inset) and are scattered among the blood vessels in the SC (Fig. 2, $B$, see inset). A number of cells localized on the capillaries and in the perivascular area in the brain white matter (Fig. 2, D, see inset) were observed.

GFAP-Ir small cells, resembling the radial astrocytes, with many tortuous processes in close vicinity to arteriols and capillaries were revealed in those cytoarchitectural zones where their small population is determined: subgranular zone of the hippocampal dentate gyrus, spinal cord (Fig. 3, $A, B$, see inset) and cerebellum (Fig. 3, $D-G$, see inset), periventricular zone of adult brain, olfactory system, region under the pia mater, subependimal zone [17].

A number of dense nestin-Ir cells of different sizes and shapes are revealed in various brain regions: fusiform cells (Fig. 4, $B$, see inset) in $\mathrm{n}$. Facialis, triangular $(C$, see inset), roundish ( $D$, see inset), cells with very short processes and negative nucleus ( $E$, see inset) and with an axon and densely stained ectopied nucleus (Fig. 4, F, see inset) in the SC anterior horn.

It is notable that round in morphology cell structures situated on the blood vessel in different brain regions demonstrate Ir for all antisera used (Figs 2, $C ; 3, A, B, F$; $4, A, D$, see inset) and strong Aph activity (Fig. $1, D$, see inset).

Brain plasticity occurs in the brain under two primary conditions: during normal brain development and as an adaptive mechanism to compensate for lost function and/or to maximize remaining functions in the event of brain injury. New neurons are generated throughout life from a population of dividing cells known as neural stem/progenitor cells (NPCs) that can differentiate into three main lineage cell types of the nervous system (neurons, astrocytes, and oligodendrocytes) when cultured in vitro. So, from NPCs in non-neurogenic regions giving rise to neurons mediated by the local 
Figures to article S. S. Abrahamyan et al.

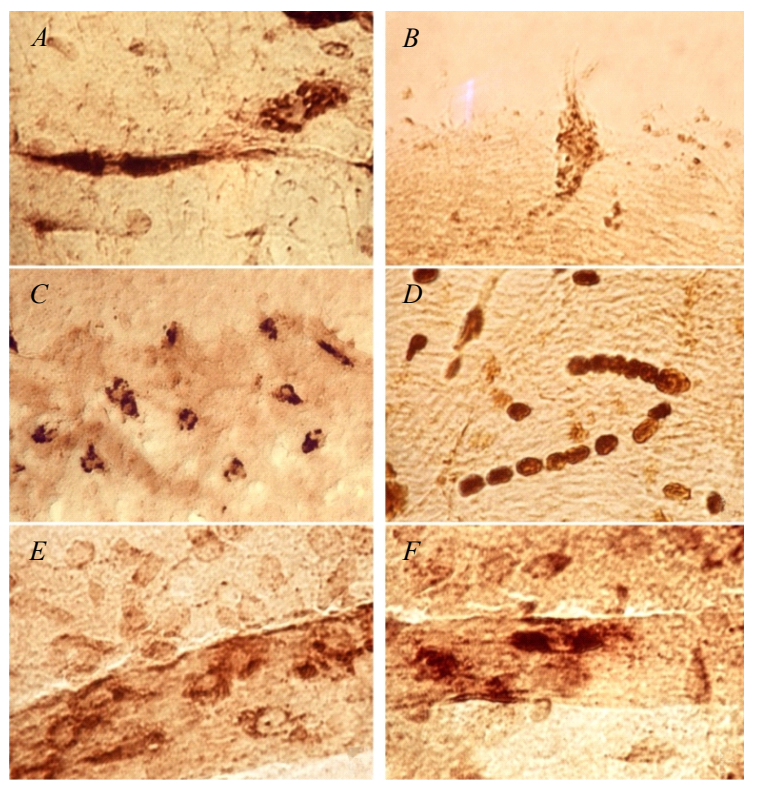

Fig. 1. Brain structures in rats exposed to prenatal stress. Two cells being in close contact via a short process $(A)$ and a large cell, half of which is yet located in the SC central canal $(B)$, cells resembling mesenchyme cells $(C)$ and many round-shape cells in the blood vessel $(D)$ are demonstrated in the cerebellum. A number of cells, most likely pericytes, are situated on an artheriol and in the perivascular area $(E, F)$. Histochemical method on detection of $\mathrm{Ca}^{2+}$-dependent acid phosphatase activity; $\times 1000$
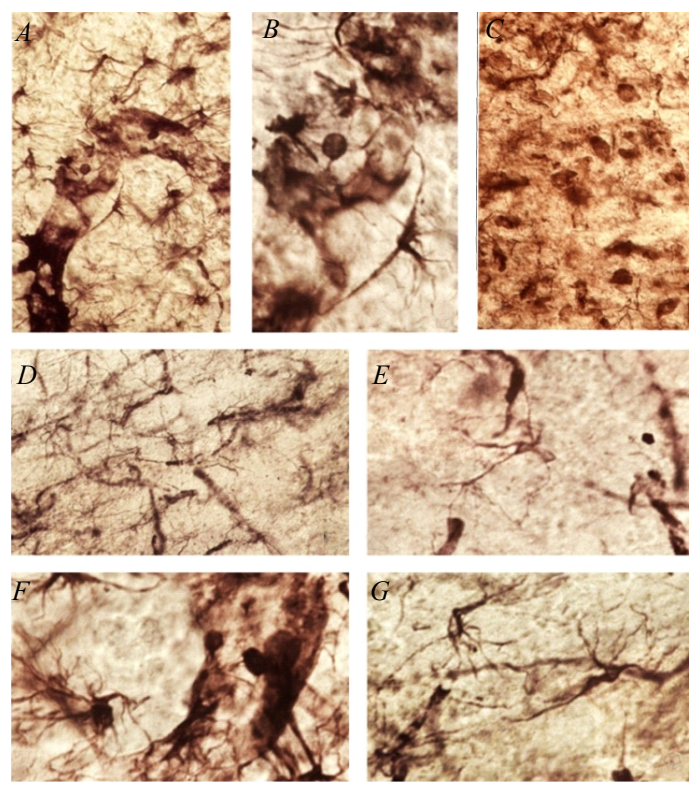

Fig. 3. GFAP Immunoreactiv structures in the brain of rats exposed to prenatal immobilization stress. $A-C$ - GFAP-Ir structures in the SC GFAP-Ir astrocytes are well seen in close proximity with the blood vessels in the SC $(A, B)$ and cerebellar white matter $(D-G) ; C$ - GFAP-Ir cell structures of different size are found in the SC dorsal horn. GFAP-Ir roundish in morphology structures are demonstrated inside of vessels in the $\mathrm{SC}(A, B)$ and cerebellar white matter $(F)$. ABC immunohistochemical method; $A, C, D, E-\times 400) ; B, F, G-\times 1000$
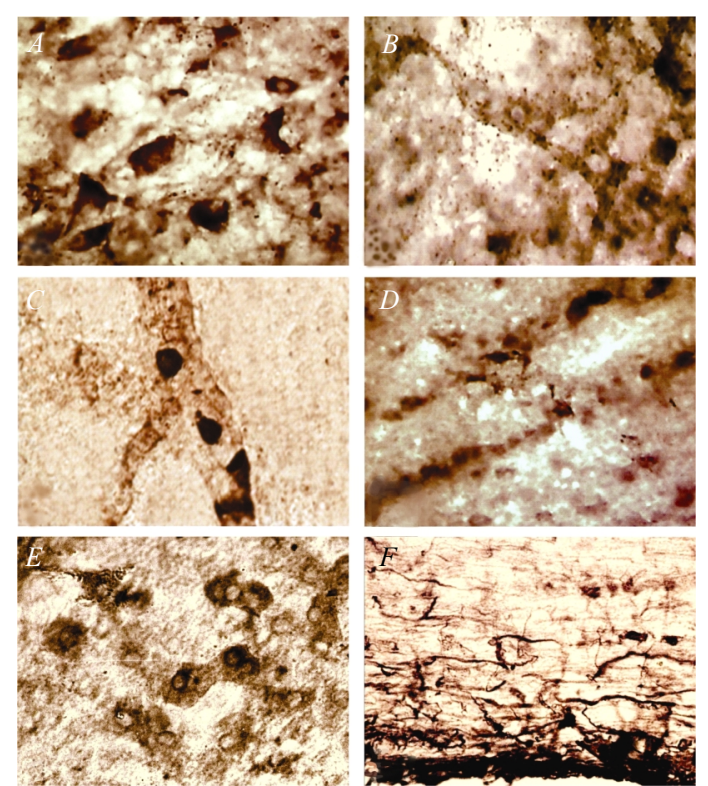

Fig. 2. PRP-1-Ir $(A-C)$ and stem cells-Ir $(E, F)$ structures in rats exposed to prenatal stress. PRP-1-Ir varicose fibers and varicosities surround cells of different sizes and shapes in the n. cochlearis $(A)$ and are scattered among the blood vessels in the SC $(B)$. Round in morphology cells are situated on the blood vessel $(C)$; a number of cells are situated in the capillaries and the perivascular area in the brain white matter $(D)$. Cells being in the proliferation stage $(E)$ and small cells with the long and tortuous processes $(F)$ demonstrate stem cells-immunoreactivity. ABC immunohistochemical method; $A, B, D-\times 400 ; C, E, F-\times 1000$
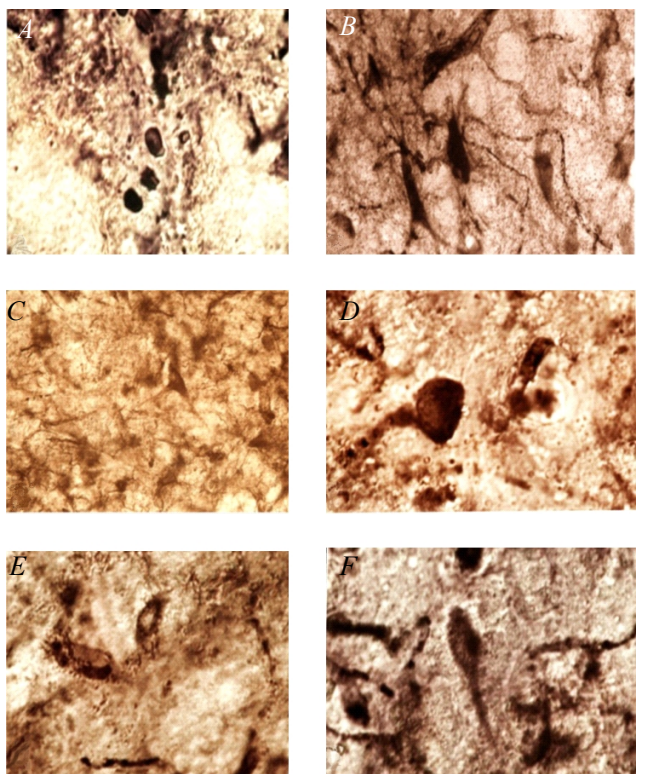

Fig. 4. Nestin-immunoreactive structures in the spinal cord and medulla oblongata of rats exposed to prenatal immobilization stress. Dense nestin-Ir cells of roundish shape $(A)$ in the n. deiters and fusiform cells $(B)$ in the n. facialis are demonstrated. $C-F$-nestin-Ir structures in the SC anterior horn; $C-F-$ a number of nestin-Ir cells of different size are revealed: $C$-triangula; $D$-roundish; $E$ - with very short processes and negative nucleus and $F$-with an axon and densely stained ectopied nucleus. ABC immunohistochemical method; $A-\times 160) ; C-\times 400 ; B, D, E, F-\times 1000$ 
astrocyte populations. The environment has also been suggested to play a key role in influencing plasticity.

In the present study we demonstrate a number of cells being in the proliferation stage (Fig. 2,E) and small cells with the long and tortuous processes (Fig. 2, $F$ ) immunoreactive for stem cells marker.

The main function of most of the multipotential progenitor cells situated in the periventricular zone of the forebrain and surrounding the SC central canal area in adult rodent CNS [18-21] is to migrate into the olfactory lobe to produce new neurones and glial cells in the normal brain [19]. It was shown in the injured SC that nestin-expressing periventricular cells start to migrate to the site of injury and to express GFAP [22]. There are also experiments in which the axons have clearly been able to regenerate in vivo on astrocyte processes [23].

Previously PRP-1-immunoreactivity was noticed in spinal glial cells both in the white matter and among the PRP-1-Ir MNs in the SC injured rats [7]. Besides, in SChemisectioned and treated with Central Asian Cobra Naja naja oxiana snake venom (NOX) rats [24] NOX has been found to result in the survival of the PRP-1-Ir neurons and increase of PRP- 1-Ir nerve fibers and astrocytes.

Bone marrow-derived stem cells are tissue-specific stem cells that are capable of self-renewal and can differentiate into cells of different tissues, including mature lineages of blood cells, neural cells both in vitro and in vivo, stromal and skeletal tissue [25].

Brain cells born in the fluid-filled ventricle migrate to the olfactory bulb via this small «superhighway» that connects them [26]. Pluripotent mesenchimal stem cells purified by Jiang et al. [27] and named multipotent adult progenitor cells (MAPCs) could differentiate into both mesenchimal and neural cells. One marker that is actually detected at the immunohistochemical level in MSCs is nestin [28, 29].

Appearance of a large cell, half of which is yet located in the SC central canal (Fig. 1, B) and PRP-1-Ir cells migrating from the $\mathrm{SC}$ central canal towards the injury area [25] allowed us to assume that they could be the BM-derived neural progenitor cells.

The stimulatory effect of PRP-1 in formation and differentiation of BM stem cells $[30,31]$ as well as in increase of PRP-1-Ir hematopoietic and mesenchimal cells (not published) of rats exposed to IMO has been suggested. Synthesis of PRP-1 in the immune system cells cannot be excluded, as well, since there is a recent evidence regarding the in vitro synthesis of PRP-1 in lymphocytes, isolated from BM.
Conclusions. Localization of the hypothalamic neuroprotective proline rich polypeptide in the above mentioned cell structures of the injured brain and SC immunoreactive to GFAP, nestin, and stem cells together with neurons and nerve fibers confirmed our suggestion that PRP-1 could be involved in this recovery mechanism, and supported the hypothesis of its role as neuro-immunological links.

\section{С. С. Абрамян, І. Б. Меліксетян, І. К. Саакян, Н. В. Тумасян, Б. Ю. Бадалян, А. А. Галоян}

Пластичність мозку щурів після дії внутрішньоутробного іммобілізаційного стресу

Резюме

Мета даного гісто- та імуногістохімічного дослідження полягала у вивченні клітинних структур мозку новонароджених щурів після дї внутрішньоутробного іммобілізачійного стресу (IMO).

Методи. Гістохімічний метод виявлення активності $\mathrm{Ca}^{2+}$-залежної кислої фосфатази та АВС-імуногістохімічний метод. Результати. У різних відділах мозку у відповідь на ІМО визначено клітинні структури, які містять маркери радіальних астроцитів GFAP, стовбурових клітин мишей, нейроепітеліальних стовбурових клітин нестину і гіпоталамічного нейропротекторного багатого на пролін поліпептиду, PRP-1 (природний цитокін під назвою Галармін, попередником якого є нейрофізин-вазопресин-асоиійований глікопротеїн). Висновки. Виявлення PRP-1 у вищезазначених клітинних структурах поряд з нейронами і нервовими волокнами вказує на прочес утворення нових нейронів у відповідь на IМО та включення PRP-1 у механізм даного відновлювального процесу.

Ключові слова: пластичність мозку щурів, внутрішньоутробний іммобілізаиійний стрес, імунореактивність стовбурових клітин PRP-1, GFAP і нестину.

\section{С. С. Абрамян, И. Б. Меликсетян, И. К. Саакян, Н. В. Тумасян, Б. Ю. Бадалян, А. А. Галоян}

Пластичность мозга крыс, подверженных внутриутробному иммобилизационному стрессу

Резюме

Цель данного гисто- и иммуногистохимического исследования состояла в изучении клеточных структур мозга новорожденных крыс, подвергшихся внутриутробному иммобилизачионному (ИМО) стрессу. Методы. Применены гистохимический метод выявления активности $\mathrm{Ca}^{2+}-$-зависимой кислой фосфатазы и АВC иммуногистохимический метод. Результаты. В различных отделах мозга в ответ на ИМО определены клеточные структуры, содержащие маркеры радиальных астроиитов GFAP, стволовых клеток мышей, нейроэпителиальных стволовых клеток нестина и гипоталамического нейропротекторного пролин-богатого полипептида, PRP-1 (природный циитокин под названием Галармин, предшественником которого является нейрофизин-вазопрессин-ассочиированный гликопротеин). Выводы. Обнаружение PRP-1 в вышеупомянутых клеточных структурах вместе с нейронами и нервными волокнами указывает на прочесс образования новых нейронов в ответ на ИМО и включение PRP-1 в механизм данного восстановительного проиесса.

Ключевые слова: пластичность мозга крыс, внутриутробный иммобилизачионный стресс, иммунореактивность стволовых клеток PRP-1, GFAP и нестина. 


\section{REFERENCES}

1. Markossian K. A., Gurvitz B. Ya., Galoyan A. A. Isolation and chemical identification of new peptides from neurisecretory granules of hypothalamus // Neurokhimiya.-1999.-16, N 1.-P. 22-25.

2. Simonian G. M., Nersissian A. K., Simonian R. M., Babayan M. A., Simonian N. A., Galoyan A. A. Antitumor and antistressor effect of hypothalamic PRP-1 in sarcoma-45 in vivo: the possible biochemical mechanisms // Neurokhimiya.-2005.-22, N 2.P. 125-130.

3. Galoian K, Scully S, Galoyan A. Myc-oncogene inactivating effect by proline rich polypeptide (PRP-1) in chondrosarcoma JJ012 cells // Neurochem. Res.-2009.-34, N 2.-P. 379-385.

4. Aprikian V. S., Galoyan A. A. Hypothalamic polypeptide preserves from death mices infected with gram-negative bacteria // Neurokhimiya.-2000.-17, N 1.-P. 60-63.

5. Galoyan A. A., Aprikyan V. S. A new hypothalamic polypeptide is a regulator of myelopoiesis // Neurochem. Res.-2002.-27, N 4.-P. 305-312.

6. Pat. No. 1696 A2, Pat. No. P20050113 Republic of Armenia. A method for treatment and/or prevention of leucosis at the cattle / A. A. Galoyan, A. A. Shirvanyan // Issued on 15.03.2006.

7. Abrahamyan S. S., Sarkissian J. S., Meliksetyan I. B., Galoyan $A$. A. Survival of trauma-injured neurons in rat brain by treatment with proline-rich peptide (PRP-1): an immunohistochemical study // Neurochem Res.-2004.-29, N 4.-P. 695-708.

8. Sarkissian J. S., Galoyan A. A., Chavushyan V. A., Meliksetyan I. B., Abrahamyan S. S., Avakyan Z. E., Aloyan M. L., Voskanyan A. V., Mkrtchyan O. A. Morpfofunctional research of protective actions of snake poison Naja Naja Oxiana at the lateral hemisection of spinal cord // Neurokhimiya.-2008.-23, N 4.P. 362-376.

9. Holtzer $H$. Cell lineages, stem cells and the «quantal» cell cycle concept // Stem cells and tissue homeostasis / Eds B. I. Lord, C. S. Potten, R. J. Cole.-New York: Cambridge Univ. Press, 1978.-P. 1-28.

10. Leblond C. P. Classification of cell populations on the basis of their proliferative behavior // Natl. Cancer Inst. Monogr.-1964.14.-P. 119-150.

11. Hsu S. M., Raine L., Fanger H. Use of avidin-biotin-peroxidase complex $(\mathrm{ABC})$ in immunoperoxidase techniques: a comparison between $\mathrm{ABC}$ and unlabeled antibody (PAP) procedures // J. Histochem. Cytochem.-1981.-29, N 4.-P. 577-580.

12. Meliksetyan I. B. Detection of $\mathrm{Ca}^{2+}$-dependent acid phosphatase activity in rat brain cellular structures // Morphologia (St. Petersburg).-2007.-131, N 2.-P. 77-80.

13. Ambrosius $X$. Obtaining of antisera from different animals // Immu nological methods / Ed. G. Frimel.-Moscow: Medicina, 1987.- P. 14-15.

14. Pelletier L., Angonin R., Regnard J., Fellmann D., Charbord P. Human bone marrow angiogenesis: in vitro modulation by substance P and neurokinin A // Br. J. Haematol.-2002.-119, N 4.P. 1083-1089.

15. Hess D. C., Abe T., Hill W. D., Studdard A. M., Carothers J., Masuya M., Fleming P. A., Drake C. J., Ogawa M. Hematopoietic origin of microglial and perivascular cells in brain // Exp. Neurol.-2004.-186, N 2.-P. 134-144.

16. Ponti G., Peretto P., Bonfanti L. Genesis of neuronal and glial progenitors in the cerebellar cortex of peripuberal and adult rabbits // PLoS One.-2008.-3, N 6.-P. e2366.

17. Gage F. H., Coates P. W., Palmer T. D., Kuhn H. G., Fisher L. J., Suhonen J. O., Peterson D. A., Suhr S. T., Ray J. Survival and differen- tiation of adult neuronal progenitor cells transplanted to the adult brain // Proc. Natl Acad. Sci. USA.-1995.-92, N 25.-P. 1187911883.

18. Canoll P. D., Musacchio J. M., Hardy R., Reynolds R., Marchionni M. A., Salzer J. L. GGF/neuregulin is a neuronal signal that promotes the proliferation and survival and inhibits the differentiation of oligodendrocyte progenitors // Neuron.-1996.17, N 2.-P. 229-243.

19. McKeon R. J., Hoke A., Silver J. Injury-induced proteoglycans inhibit the potential for laminin-mediated axon growth on astrocytic scars // Exp. Neurol.-1995.-136, N 1.-P. 32-43.

20. Powell E. M., Meiners S., DiProspero N. A., Geller H. M. Mechanisms of astrocyte-directed neurite guidance // Cell Tissue Res.-1997.-290, N 2.-P. 385-393.

21. Zuo J., Neubauer D., Dyess K., Ferguson T. A., Muir D. Degradation of chondroitin sulfate proteoglycan enhances the neuritepromoting potential of spinal cord tissue // Exp. Neurol.-1998.154, N 2.-P. 654-662.

22. Keirstead H. S., Dyer J. K., Sholomenko G. N., McGraw J., Delaney $K$. R., Steeves $J$. D. Axonal regeneration and physiological activity following transection and immunological disruption of myelin within the hatchling chick spinal cord // J. Neurosci.1995.-15, N 10.-P. 6963-6974.

23. Kruger S., Sievers J., Hansen C., Sadler M., Berry M. Three morphologically distinct types of interface develop between adult host and fetal brain transplants: implications for scar formation in the adult central nervous system // J. Comp. Neurol.-1986.249, N 1.-P. 103-116.

24. Abrahamyan S. S., Meliksetyan I. B., Chavushyan V. A., Aloyan M. L., Sarkissian J. S. Protective action of snake venom Naja naja oxiana at spinal cord hemisection // Ideggyogy Sz.-2007.-60, N 3-4.-P. 148-153.

25. Grove J. E., Bruscia E., Krause D. S. Plasticity of bone marrowderived stem cells // Stem. Cells.-2004.-22, N 4.-P. 487-500.

26. Aimone J. B., Jessberger S., Gage F. H. Adult neurogenesis // Scholarpedia.-2007.-2, N 2.-P. 2100.

27. Jiang Y., Jahagirdar B. N., Reinhardt R. L., Schwartz R. E., Keene C. D., Ortiz-Gonzalez X. R., Reyes M., Lenvik T., Lund T., Blackstad M., Du J., Aldrich S., Lisberg A., Low W. C., Largaespada D. A., Verfaillie C. M. Pluripotency of mesenchymal stem cells derived from adult marrow // Nature.-2002.-418, N 6893.P. 41-49.

28. Lu P., Blesch A., Tuszynski M. H. Induction of bone marrow stromal cells to neurons: differentiation, transdifferentiation, or artifact? // J. Neurosci. Res.-2004.-77, N 2.-P. 174-191.

29. Vogel W., Grunebach F., Messam C. A., Kanz L., Brugger W., Buhring $H$. J. Heterogeneity among human bone marrow-derived mesenchymal stem cells and neural progenitor cells // Haematologica.-2003.-88, N 2.-P. 126-133.

30. Bezirganyan K. B., Galoyan A. A., Davtyan T. K. Hypothalamic proline-rich polypeptide enhances human $\mathrm{CD} 34+$ progenitor cell differentiation into erythroid and granulomonocytic linea ges // Neurochem. J.-2008.-2, N 4.-P. 305, DOI: 10.1134/ S1819712408040144.

31. Galoyan A. A., Korochkin L. I., Rybalkina E. J., Pavlova G. V., Saburina I. N., Zaraiski E. I., Galoyan N. A., Davtyan T. K., Bezirganyan K. B., Revishchin A. V. Hypothalamic proline-rich polypeptide enhances bone marrow colony-forming cell proliferation and stromal progenitor cell differentiation // Cell Transplant.-2008.-17, N 9.-P. 1061-1066. 